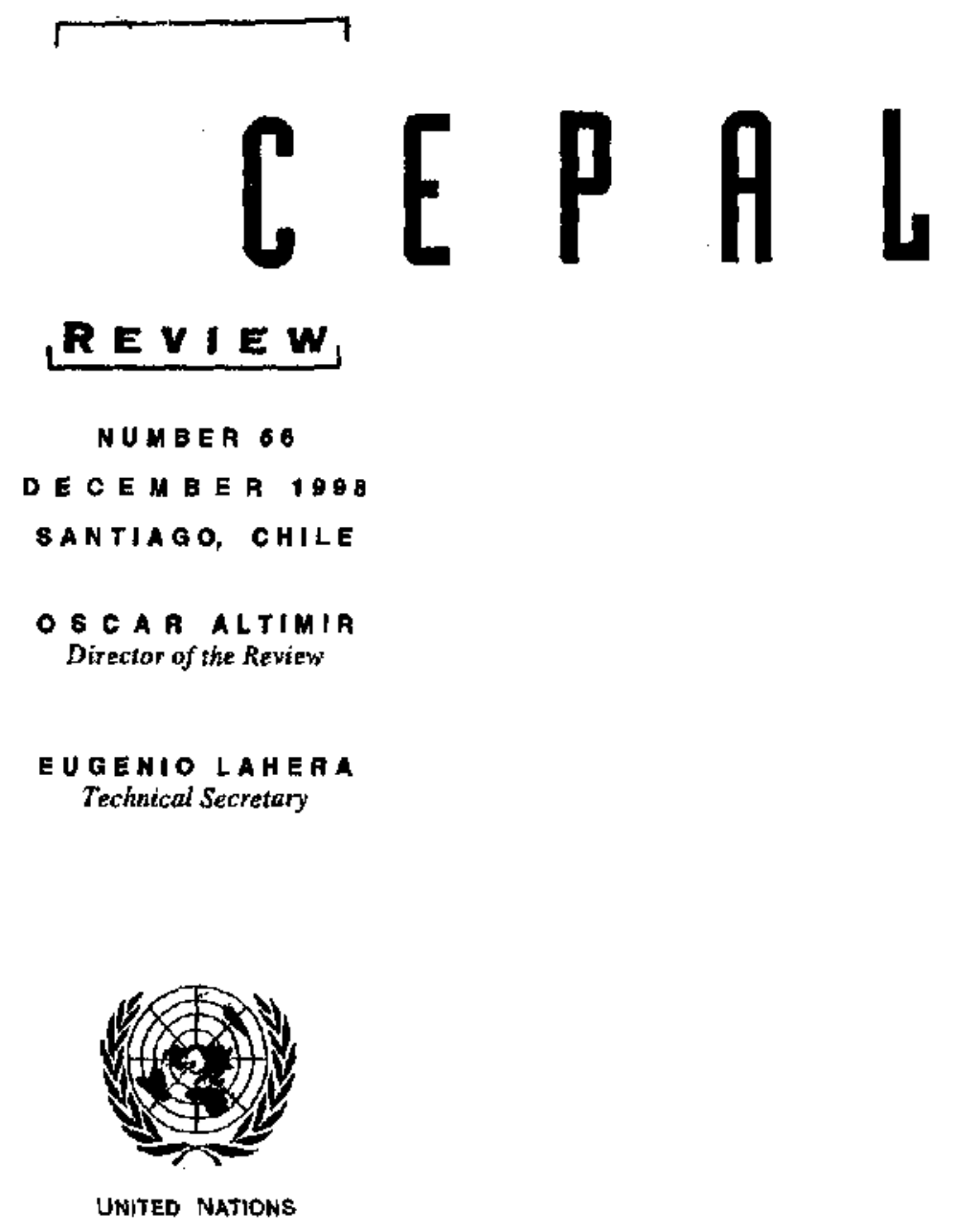


CONTENTS

Beyond the Washington Consensus: an ECLAC perspectlve

José Antonio Ocampo

The Cuban economy

David Ibarra and Jorge Máttar

Education in Latin America: demand and distribution are factors that matter

Nancy Birdsall, Juan Luis Londoño and Lesley O'Connell

Determinants of inequality among urban households

Luis Felipe Jiménez $L$, and Nora Ruedi $A$.

Health management contracts in Costa Alca from a comparative perspective

Ana Sojo

A development strategy tounded on natural resource-based production clusters

Jaseph Ramos

Blg Latin American industrial companies and groups

Celso Garrido and Wilson Peres

Between political control and efflciency gains:

the evolution of agrarian property rights in Mexico

Gustavo Gordillo, Alain de Janvry and Elizabeth Sadoulet

Tariffs and the Plano Real in Brazil

Renaso Baumann, Josefina Rivero and Yohana Zavattiero 


\section{Tariffs and the}

\section{Plano Real in Brazil}

Renato Baumann

Joepfina Rivero

Yohana Zavattiero

ECLAC Brasilia Office.
This article analyses the economic rationale of Brazil's tariff policy during the first two years of the Plano Real. To this end, a study is made of the changes made in import duties for all the products traded. The tariff reform process in Brazil was begun in 1988, after the old Tariff Act had been in effect for thirty years, and represented a marked intensification in the process of trace openness, with the definition of a schedule of gradually decreasing tariffs which was further speeded up as from 1990. The Plano Real began in July. 1994 and had many effects on import policy. The trade liberalization process reached its beight in the first quarter of 1995 in terms of the average level of tariffs and their degree of dispersion. Since then there have been several episodes of tariff increases, differentiated by sectors, which have increased the degree of dispersion of the tariff structure. If two sectors with special treatment (petroleum and motor vehicles) are excluded, a direct relation may be observed between the value of imports and the nominal tariff level, with pronounced variations over the period studied. At the same time, the fact that for some sectors the tariff rate weighted by the value of imports was below the average rate for a number of months indicates that there are grounds for reviewing tariff levels in some cases. The article concludes with some observations on the performance of import policy. 


\section{I}

\section{Introduction}

The Brazilian economy is often cited in the literature on foreign trade policy. A number of studies have also analysed the multiplicity of instruments adopted as barriers to imports that compete with domestic products (especially in the $1960 \mathrm{~s}$ and 1980s), the mechanisms used in practice to circumvent these barriers through the application of special import arrangements, the various export incentives, the process of definition of import duties, and the concern to neutralize possible skews in trade policy.

Not long ago, in 1988, Brazil embarked on a process of reform of the tariff structure which had existed for the past 30 years under the Tariff Act, which underwent some changes in 1989 and many more in 1990.

The adoption of the Plano Real in July 1994 had a number of effects on import policy. The incomeeffects and price-effects of a successful stabilization programme provide a natural stimulus for the demand for imported goods. Moreover, the concern to ease access to cheaper imported products had the dual effect of exerting pressure on groups which had an oligopolistic position in the domestic market and promoting greater efficiency of the production system.

In addition to the concern for price stability, there was the conjunctural matter of the proximity of the date fixed for the entry into effect of the tariff structure negotiated with the other members of Mercosur: the Common External Tariff was due to come into force on 1 January 1995. The second half of 1994 was therefore marked by continual changes in import tariff rates.'

This question was already dealt with very effectively by Kume (1996), while Nonnemberg (1996) analysed other related policy measures; the first of these authors deals with the evolution since 1988 of the effective rates of protection given to the various sectors of production, while the second author highlights the importance of financial arbitrage move ments as a stimulus for financing imports. ${ }^{2}$

In the present article, we will try to identify the economic rationale of Brazilian tariff policy by examining the effect of each of the various changes in import tariff rates for all the products traded. The period covered is from July 1994, when the Plano Real began, to the end of September 1996, which was the latest month for which data were available at the time of writing. All the decrees and decisions affecting tariff rates were taken into account, thus permitting a full description of the evolution of national import policy in the first two years of the Plano Real. The methodological annex shows how the primary data were processed.

\section{II}

\section{Evolution of the tariff structure}

In the course of the present decade, Brazilian external trade policy has evolved in the direction of reducing trade barriers, which has been reflected in a corresponding increase in the value of imports (table 1).

It may be noted from table 1 that although tariff rates have tended to go down steadily (except for a

$\square$ This study could not have been made without the efficient computational support of Decio Fialho of ECLAC. Equally important support was provided by Asdré Bauer in processing the data. slight reversal in the last year) and that this has corresponded to a rise in the total value of imports, the rate of such tariff reduction displays variations which are worthy of our attention. Thus, between 1990 and

\footnotetext{
${ }^{1}$ It may be noted that the priorities laid down in the Plano Real -in effect from 1 July 1994- also strongly influenced national policy on convergence with the Common External Tariff.

2 For a relatively full description of the period preceding the adoption of the Plano Real (1958-1993), see Pinlueiro and Almeida (1995).
} 
TABLE I

Brazll: Import dutles and

value of Imports, 1990-1996

\begin{tabular}{lcc}
\hline Year & $\begin{array}{c}\text { Simple average } \\
\text { rate } \\
\text { (per cent) }\end{array}$ & $\begin{array}{c}\text { Value of imports } \\
\text { (Millions of } \\
\text { doliars FoB) }\end{array}$ \\
\hline 1990 & 32.12 & 20661 \\
1991 & 25.19 & 12042 \\
1992 & 20.78 & 20554 \\
1993 & 16.49 & 22797 \\
1994 & 13.97 & 33106 \\
1995 & 13.07 & 49263 \\
1996 (Jan/Sep.) & 13.10 & 49619 \\
\hline
\end{tabular}

Source: Estimates provided by H. Kume and figures prepared by the authors on the basis of primary data.

1993 the simple average tariff rate went down by half, whereas the most noteworthy increases in imports took place in the most recent period. Furthermore, there has been a relative stabilization of import tariffs since 1994 but, as we shall see below, this apparent stability actually conceals a varied set of parallel reductions and increases in the rates for different products.

In order to explain the different rates of change of import duties and of the increase in the value of imports, it is necessary to take into account various other relevant elements, such as exchange rate policy, the income-effect of the demand for imported products, the existence of special import regimes, and even an aspect which is usually neglected in most studies: i.e., the process of familiarization of consumers with foreign-made products which were not obtainable on the domestic market for decades. This latter element is a slow process which involves the establishment and consolidation of domestic marketing channels for the imported goods, and it undoubtedly explains -at least in part- the time-lag in the response of demand for these products.

\section{General features of the trade openness process}

a) The products affected and the average tariffs

The first aspect to be noted when analysing import policy in the first two years of the Plano Real is that the variations ${ }^{3}$ in import duties affected $83 \%$ of the total list and $28 \%$ of the products affected under-

\footnotetext{
${ }^{3}$ Note that it is a question of "variations" and not necessarily of "reductions".
}

TABLE 2

Brazl: Incidence of changes In import dutles, July 1894 to September 1996

\begin{tabular}{lcc}
\hline & $\begin{array}{c}\text { Number of } \\
\text { products }\end{array}$ & Per cent \\
\hline $\begin{array}{l}\text { Total number of products studied } \\
\begin{array}{l}\text { Products which underwent a } \\
\text { change in rate }\end{array}\end{array}$ & 13428 & 100.0 \\
$\begin{array}{l}\text { Products with two or more } \\
\text { changes in rate } \\
\text { Products with three or more }\end{array}$ & 11183 & 83.3 \\
$\begin{array}{l}\text { changes in rate } \\
\text { Products with five or more } \\
\text { changes in rale }\end{array}$ & 938 & 28.5 \\
\hline
\end{tabular}

Source: Prepared by the authors on the basis of primary data.

went two or more changes in tariff rates in the period between July 1994 and September 1996. In other words, this was undoubtedly a time of marked redefinition of the country's trade relations with the rest of the world.

The figures in table 2 indicate that in this period there was heavy intervention in the import tariff structure. Some specific products (at the ten-digit level of classification) even underwent several changes in the nominal rate. In the case of 148 products there were five changes or more, which -over a period of only 27 months- may have become a disturbing element in the formation of expectations by the economic agents.

There was a similar picture of differences in the rates of trade openness and import performance over this period (table 3 and figure 1).

Over the period in question there was an initial spell (in the last two quarters of 1994) of marked reduction of import duties which -in conjunction with other factors- resulted in a significant increase in the value of imports. At the beginning of 1995 there was a slight increase in the simple average rate, and from the second quarter of 1995 on this rate reached a level of around $13 \%$ which has been maintained since then. The quarterly value of imports evolved differently: it practically doubled between the third quarter of 1994 and the second quarter of 1995 , fell slightly in the following quarter, and (subject to small fluctuations) has remained at that level (around US\$12 billion) since then, with a new surge in the third quarter of 1996.

The last three columns of table 3 give some important supplementary information. Before considering them, however, a brief methodological digression is called for in order to highlight the importance of 
TABLE 3

Brazll: Quarterly value of Imports, rates of Import duty, and number of products affected, 1994-1996

\begin{tabular}{|c|c|c|c|c|c|c|}
\hline \multirow{2}{*}{ Period } & & \multirow{2}{*}{$\begin{array}{l}\text { Value of imports } \\
\text { (Millions of } \\
\text { doillars CIF) }\end{array}$} & \multirow{2}{*}{$\begin{array}{l}\text { Simple rate } \\
\text { (per cent) }\end{array}$} & \multicolumn{3}{|c|}{ Number of episodes of changes in rates } \\
\hline & & & & Reductions & Increases & Total \\
\hline \multirow[t]{2}{*}{1994} & IIJ & 7931 & 13.0 & 4738 & 21 & 4759 \\
\hline & IV & 11824 & 11.2 & 253 & 22 & 275 \\
\hline \multirow[t]{4}{*}{1995} & I & 12017 & 12.6 & 2462 & 5349 & 7811 \\
\hline & II & 13656 & 13.2 & 468 & 401 & 869 \\
\hline & III & 11916 & 13.2 & 84 & 85 & 169 \\
\hline & IV & 12030 & 13.3 & 63 & 97 & 160 \\
\hline \multirow[t]{3}{*}{1966} & I & 10737 & 13.1 & 1738 & 303 & 2041 \\
\hline & II & 12477 & 13.0 & 195 & 171 & 366 \\
\hline & III & 14965 & 13.2 & 13 & 150 & 163 \\
\hline
\end{tabular}

Source: Prepared by the authors on the basis of prijnary data.

FGURE I

Brazil: Tariff rates and imports

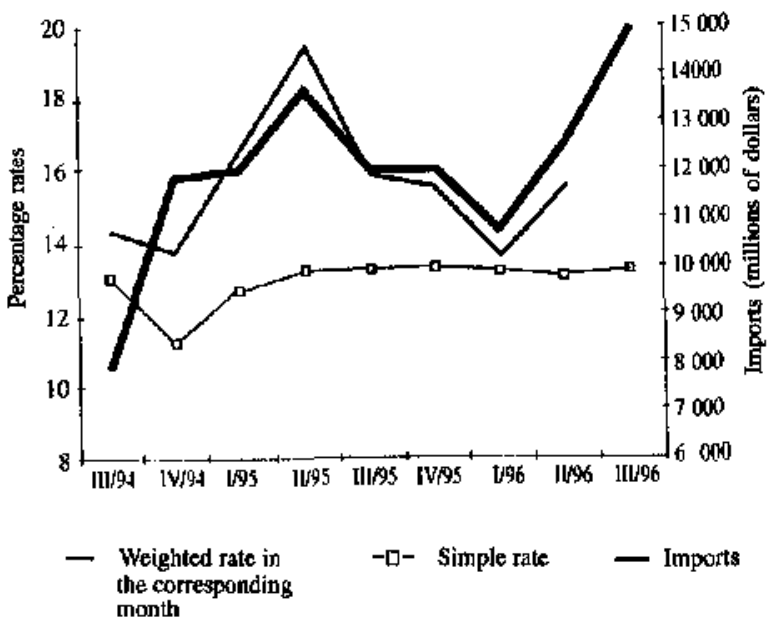

including the indicator on the number of variations in the rates.

If we take as an example what happened between December 1994 and January 1995, we note that the simple average import tariff rate suggests that there was a generalized rise in import duty, which rose from $11.19 \%$ in the first month to $12.62 \%$ in the second. However, these figures are the net result of a policy under which there were 5093 tariff increases at the same time that there were 2691 reductions. In other words, it would be desirable not to limit our analysis to the general level but to take account also of the data at a more detailed level.

Table 3 clearly shows that the changes in the tariff structure were actually concentrated (judging from the number of episodes of changes in rates) in the third quarter of 1994 and the first quarter of $1995,{ }^{4}$ and that this was not a continuous process.

Although the number of cases of tariff reduction predominates over the period as a whole, there were also tariff increases for a substantial number of products, especially in the first quarter of 1995 (particularly for those products which had to adapt their tariff levels to the Common External Tariff) and also early in 1996 (although the increases, which were adopted in order to correct the trade balance, were not so marked on this occasion).

The global results of these movements (compared with the "simple" rates) are shown in figure 2.

There was a clear downward trend in the average tariff at the end of 1994, which actually represents the continuation of a process begun in 1990 (as shown in figure 2), with relative stability around the median as from the second quarter of 1995. The most frequent rate reached its minimum level in the first quarter of 1995 and stabilized at $18 \%$ as from the second quarter of that year.

Protection theory recommends that if the adoption of import tariffs cannot be avoided, then the distortions introduced into the economic system will be minimized if the rates of import duties and their dispersion are kept as low as possible. Thus, according to this theory, a reform which reduces tariff levels and also reduces the variance in the distribution of the tariff rates is a step in the right direction.

\footnotetext{
4 With a little additional variation in the first quarter of 1996.
} 
FGURE 2

Braxil: Indlcators of recent tarlff policy

Per cent

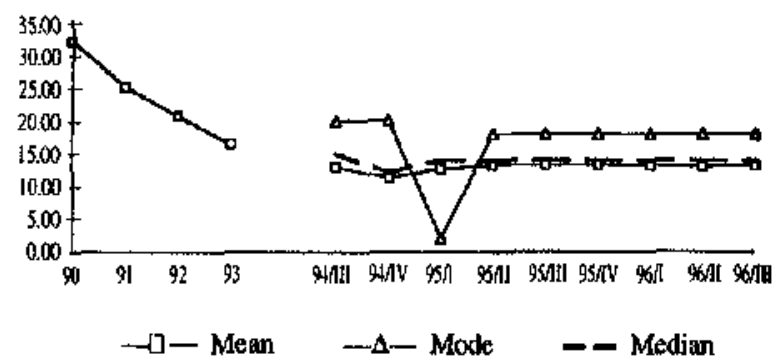

However, analysis of the evolution of the tariff structure suggests that the behaviour was uneven, to judge from the deviation pattern of the tariff rates:

\begin{tabular}{|c|c|c|c|c|c|c|c|c|}
\hline \multicolumn{2}{|c|}{1994} & \multicolumn{4}{|c|}{1995} & \multicolumn{3}{|c|}{1996} \\
\hline III & IV & I & II & III & IV & I & II & III \\
\hline 8.0 & 7.9 & 7.2 & 9.4 & 9.6 & 9.8 & 9.0 & 8.4 & 8.9 \\
\hline
\end{tabular}

These figures indicate that initially, up to the first quarter of 1995 , there was a move towards greater uniformity of the tariff structure (at lower rates), but there was growing dispersion in the rest of that year, followed by a lack of convergence throughout 1996.

\section{b) The weighted rates}

So far, the data have been presented on the basis of simple rates (i.e., measurements weighted only by the period of validity) and in aggregated form. It is known, however, that during the period in question there were substantial changes in the country's list of imports. In 1993, for example, imports of consumer goods represented $12 \%$ of the total value of imports, but this proportion rose to $17 \%$ in 1994 and $22 \%$ in 1995.

This means that we must consider the tariff structure in the light of the effective weight of the products concerned: $i$.e., we must consider the import tariff rates weighted by the value of imports of each product.

The exceptional growth of trade flows in this period raises the further difficulty of identifying the most suitable import vector for this weighting. The structure for the immediately preceding period does not reflect the changes made, and the years 1994 and
1995 must be considered atypical because they reflect import demand structures which were heavily influenced by the initial phase of a stabilization process.

The most feasible alternative was -as described in the preceding section- to weigh the vector of the simple rates by the import structure in the 1990-1993 period (as the reflection of a minimum pattern) and by the import structure in 1995 (reflecting a maximum pattern), complementing the analysis with estimates of the rates as weighted by the current value of imports: i.e., the value actually registered in each quarter.

Table 4 and figure 3 show the differences in the weighting criteria

The three estimates of weighted rates show a sharp drop in tariffs in the last quarter of 1994, a recovery in the next two quarters, a new reduction in the second half of 1995 and a slight increase in 1996.

Analysis of these data and of the figure shows that: i) the behaviour of the simple tariff is not capable of reflecting this movement; ii) the changes in the structure of the import list over the period were sufficiently pronounced to give substantially different results when the data are weighted by the average for the previous three years or for a period of markedly high demand such as 1995; and iii) weighting by the value of imports in the same quarter gives results which are less skewed, with values intermediate between the results obtained with the other two weighting methods. ${ }^{5}$

These results show the need to make the analysis more detailed in order to take account of the movements in each quarter -the relation between the value of imports and the rate of duty- and the policies applied in respect of particular sectors.

\footnotetext{
S It should be noted that the import values are only partly a response to the levels of import duties: according to the Ministry of Federal Revenues (data published in the Gazeta Mercantil of 11 December 1996), if we consider the relation between the value of imports and the amount effectively paid in import duties in the first ten months of 1996 , then Brazil's imports were brought in at an average real rate of $7.1 \%$, which is a good deal lower than the average nominal rate of $13.6 \%$ estimated by that Ministry. This is explained by the effect of "special import regimes" which ensure differential treatment for some imported products. In sectoral terms, the same study also reveals manifest differences, as in the case of transport equipment, where the nominat tate of duty in 1996 was $19.78 \%$ but the real duty was $6.46 \%$, or consumer goods, where the nominal rate was $24.38 \%$ but the "real" rate was $11.12 \%$.
} 
TABLE 4

Brazll: Simple and weighted rates of import duty, by quarters, 1994-1896

\begin{tabular}{|c|c|c|c|c|c|}
\hline \multirow{2}{*}{ Period } & & \multirow{2}{*}{$\begin{array}{l}\text { Simple rate } \\
\text { (per cent) }\end{array}$} & \multicolumn{3}{|c|}{ Weighted rate (per cent) } \\
\hline & & & $\begin{array}{c}\text { Average } \\
1990-1993\end{array}$ & Current quarter & $\begin{array}{l}\text { Comresponding } \\
\text { quarter in } 1995\end{array}$ \\
\hline 1994 & $\begin{array}{l}\text { III } \\
\text { IV }\end{array}$ & $\begin{array}{l}12.95 \\
11.19\end{array}$ & $\begin{array}{r}13.45 \\
9.92\end{array}$ & $\begin{array}{l}14.36 \\
13.68\end{array}$ & $\begin{array}{l}14.85 \\
14.02\end{array}$ \\
\hline 1995 & $\begin{array}{l}\text { I } \\
\text { II } \\
\text { III } \\
\text { IV }\end{array}$ & $\begin{array}{l}12.62 \\
13.18 \\
13.22 \\
13.26\end{array}$ & $\begin{array}{l}13.04 \\
13.74 \\
13.49 \\
13.44\end{array}$ & $\begin{array}{l}16.57 \\
19.46 \\
15.79 \\
15.49\end{array}$ & $\begin{array}{l}16.57 \\
19.46 \\
15.79 \\
15.49\end{array}$ \\
\hline 1996 & $\begin{array}{l}\text { I } \\
\text { II } \\
\text { III }\end{array}$ & $\begin{array}{l}13.13 \\
12.99 \\
13.19\end{array}$ & $\begin{array}{l}12.70 \\
12.86 \\
13.03\end{array}$ & $\begin{array}{c}13.51 \\
15.47 \\
\ldots\end{array}$ & $\begin{array}{l}18.39 \\
19.72 \\
16.45\end{array}$ \\
\hline \multicolumn{2}{|c|}{$\begin{array}{l}\text { Global average for the period } \\
\text { July } 1994 \text {-September } 1996\end{array}$} & 12.86 & 13.16 & 15.54 & 16.75 \\
\hline
\end{tabular}

Source: Prepared by the authors on the basis of primary data.

FOURB 3

Bradl: Woighted Iniport tariff rotes

Per cent

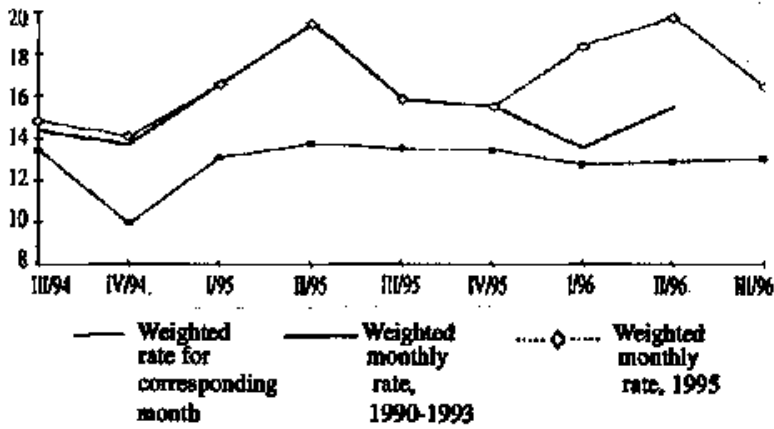

Before proceeding to make this detailed analysis, however, some comments are called for on the relationship between the national tariff structure and the Common External Tariff agreed with the other members of Mercosur.

\section{The myth of the advance adoption of the Common External Tariff (CET)}

It was thought that Brazil would bring forward to September 1994 the country's adoption of the Common External Tariff (CET) agreed within Mercosur and scheduled to come into effect in January 1995, but closer analysis reveals that this assertion calls for some reservations.
The belief that the CET would be applied three months in advance was due to Resolutions 506 and 507 of the Ministry of Finance, both dated September 1994. In fact, three important resolutions were adopted in that month: No. 492 , which reduced the import duties for a number of products to a uniform level of $20 \%$, and Nos. 506 and 507, which changed the specific rates for a list of products.

At the end of September 1994, however, after the entry into force of the three resolutions, there were still 124 products with import duties of over $20 \%,{ }^{6}$ and not all of them corresponded to the ex ceptions provided for in the case of the information processing sector (only 48 products under item 84.71) and the telecommunications sector (only 6 products under item 85.17).

Furthermore, examination of the Brazilian tariff structure at the end of September 1994 shows that there were 2930 products with rates higher than those of the CET, 5102 with rates that were lower, and 5396 with rates equal to those of the CET.

In other words, at the end of September the CET tariff structure only applied to $42 \%$ of the total number of products on the import list. Thus, Brazil only partially applied the CET in advance. ${ }^{7}$ The effective adoption of the Common External Tariff and the

\footnotetext{
- Compared with 452 products in August of the same year.

${ }^{7}$ Combined with tariff reductions to levels below those laid down in the CET, for the purpose of domestic price stabilization.
} 
Common Nomenclature only took place as from 1 January 1995, through Decree No. 1343. This does not mean to say that the convergence effort was not appreciable; it is simply meant to show that the CET was not applied in full before the scheduled date.

Another important observation for understanding the evolution of the Brazilian tariff structure in this period concerns the lists of exceptions. Between April and December 1995, in an effort to bring down domestic price levels through competition from imports, the government adopted Decrees Nos. 1453, $1471,1490,1550,1678$ and 1767, which established lists of products temporarily subject to differential tariff treatment. ${ }^{8}$ In April 1996, Decree No. 1848 established another list of exceptions.

With regard to the products affected, in January 1995 , when the CET was adopted, there were 1272 products on the list of exceptions (annex to Decree No. 1343), and this figure rose to 1700 products in December of that year, as a result of the adoption of the two decrees already mentioned, which were consolidated in Decree No. 1767. In April 1996, Decree No. 1848 consolidated a new list of exceptions containing 1500 products.

If we look at the whole set of movements effected in this period, in relation to the number of times the rates were changed (not the products affected), we see that for the period from July 1994 to September 1996 this number was broken down as follows:

i) Partial adaptation of the Brazilian customs tariffs to the CET in September 1994 accounted for $23 \%$ of the cases, all involving tariff reductions.

ii) The application of the CET in January 1995 accounted for $47 \%$ of the total number of changes in tariffs: $32 \%$ increases and $15 \%$ reductions.

iii) The adoption of lists of exceptions accounted for $23 \%$ of the total: $16 \%$ reductions and $7 \%$ increases.

These data help us to understand the evolution of the weighted average rate of import duties. Figure 1 shows that there was an initial downward movement

The changes made during 1995 may be sunmarized as follows: a) Decree No. 1471 consolidaled the exceptions to the Common Extemal Tariff (annex 1 of the Decree gives the national list of exceptions and annexes 2 and 3 correspond to the so-called Dallari list); b) Decree No. 1490 establisbed a new annex 1 which superseded the previous one; c) Decree No. 1550 corrected and slightly anended the Common Extemal Tariff; and d) Decree No. 1678 repeated the foregoing procedure. We are indebted to Honorio Kume for this information.
FGURE 4

Brazll: Import duty rates and

Import values - monthly figures

(Percentage rates and import values in millions of dollars)

Per cent

Millions of US\$

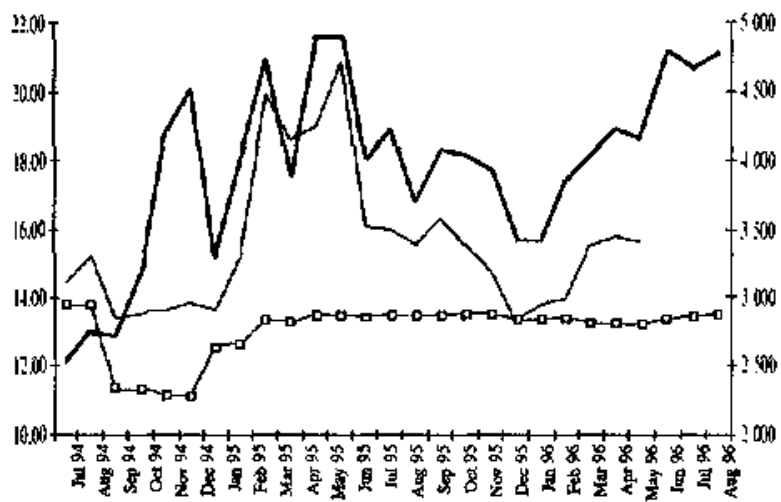

T- Simple rale - Weightod rate for - Imports

in the fourth quarter of 1994, reflecting the partial advance application of the CET (and the additional adjustment in the tariff structure), followed by an increase when the Common External Tariff was applied in full, reaching a peak in the second quarter of 1995. Subsequently, up to the first quarter of 1996 , new reductions were made on three occasions, reflecting the effect of the lists of exceptions, and thereafter there was an upward trend in tariff levels.

Analysis of the monthly data on the "simple" rate of import duties and the value of imports (see figure 4) also shows three distinct periods:

i) Initially, in July and August 1994, the total value of imports begins to rise, even before the changes in the tariff structure: the most likely explanation for this is the income-effect of the Plano Real, associated with the revaluation of the exchange rate.

ii) In a second period (between September and December 1994) the level of the "simple" tariff rate is reduced. In this period there is clearly an extra stimulus for imports due to the variation in the "simple" rate and the persistence of the incomeeffect and price-effect from the previous period.

iii) As from 1995 (especially as from March) the "simple" rate stabilizes around 13\% (while at the same time the exchange rate changes again). The fluctuations in the total value of imports persist, however. Altogether, this set of data suggests that as from 
the second quarter of 1995 the "simple" rate loses its capacity to determine imports: its influence seems to be limited to the level of the value of imports, but it does not explain the variations in this indicator, which tends to depend on other determinants such as exchange-rate and other policies.

The behaviour of the weighted rate reflects these three periods: it rises between July and August 1994 (even with a constant "simple" rate), remains stable between September 1994 and January 1995 (the reduction in the rate is offset by the increase in imports), and thereafter it directly reflects the variations in the value of imports.

This behaviour suggests that there are other factors that should be taken into account, especially analysis of the behaviour at the level of the most important sectors.

\section{Tariffs by eectors}

For this sectoral analysis, we selected 14 of the 97 chapters (two-digit categories) of the Nomenclatura Brasileira de Mercadorias/Harmonized System on the basis of two criteria: i) the number of variations in import duties they underwent in the period studied, and ii) their relative importance in the total value of imports.

The 14 chapters selected in line with these criteria accounted in 1995 for $74 \%$ of the total value of imports and $67 \%$ of the number of variations in tariff rates in the period in question. In other words, these chapters accounted for the major part of the variations in import duties between July 1994 and September 1996. These chapters also account for $65 \%$ of the total number of products (at the ten-digit level) affected by changes in tariff rates."

Table 5 summarizes the basic information. It will be noted from it that -as in the universe of the import list- the number of reductions of tariff rates amply exceeds the number of increases in the period. In this sample of 14 tariff chapters, there were increases in

\footnotetext{
${ }^{9}$ The chapters were: Chap. 11 - Milling industry products; Chap. 27 - Mineral fuels and mineral oils; Chap. 28 - Inorganic chemical products; Chap. 29 -Organic chemical products; Chap. 39 Plastics and products thereof; Chap, 48 - Paper and paperboard; Chap. 54 -Synthetic or artificial filaments; Chap. 55 - Synthetic or artificial fibres; Chap. 72 - Cast iron, iron and steel; Chap. 73 - Cast iron, iron or steel, worked; Chap. 84 -Machinery and mechanical equipment; Chap. 85 - Electrical equipment and components; Chap. 87 - Motor vehicles and other land transport equipment; Chap. 90 - Optical instruments and equipment.
}

$59 \%$ of the cases, whereas there were reductions in $72 \%$. This reflects the sectoral dispersion of the trade liberalization process.

The fourth, fifth and sixth columns of table 5 also show that the "simple" rates for these' 14 chapters were always higher than the rates for the total number of products.

This relation was maintained systematically. Figure 5 shows a comparison between the evolution of the rates in the sample and those of the whole 97 chapters during the period studied. Both show a marked reduction between July and September 1994 and relative stability as from May 1995. However, the "simple" rate for the 14 chapters is systematically higher than the rate for the totality of products, which explains the above-mentioned difference between the percentage shares of the sample group in the episodes of reduction and increase of rates.

Furthermore, as a result of the import policy; during the period in question there was a direct and systematic relation between the rates of duty on imports and the value of imports of the products in question (see table 6). ${ }^{10}$

Analysis of table 6 reveals that on average the products with the greatest weight in the total value of imports were subject to higher rates. There is a direct relation for each import value bracket.

Part of the explanation for these results must be sought in the policy on the sectors to which these products belong. The data indicate that the highest rates for this set of products were observed in the case of synthetic textiles, footwear, buses and utility vehicles, which suggests concern about the effects of imports on domestic producers.

For all the sectors studied, there was a sustained reduction of import duties between 1990 and 1993. In some cases, this reduction was quite marked, as for example in the case of milling industry products, where the tariff was reduced from $28.8 \%$ in 1990 to $9.9 \%$ in 1993 . Other significant reductions were in plastics and plastic products, machinery and me-

\footnotetext{
10 This table shows the average level of the "simple" rates in effect during the period studied, by import value brackets. There were two products with import values over a million dollars in 1995: passenger vehicles and petroleum. As imports of petroleum are totally regulated in Brazil -this being a product with a very particular market- and as automobile import policy displayed extreme variations in the period, we decided not to include the data on these two products in the table, in order to avoid distortions.
} 
TABLE 5

Brazil: Selected chapters, by number of veriations in

Import duty rate and/or valative importance in total imports

\begin{tabular}{|c|c|c|c|c|c|c|c|c|c|c|}
\hline \multirow{2}{*}{$\begin{array}{l}\text { Selected } \\
\text { chapters of } \\
\text { NBM/HS }\end{array}$} & \multicolumn{2}{|c|}{ Vaiue of imports in 1995} & \multicolumn{3}{|c|}{ Simple average rales } & \multicolumn{4}{|c|}{ Total number of changes in rates in period } & \multirow{2}{*}{$\begin{array}{l}\text { Number of } \\
\text { prodiucts } \\
\text { affected } \\
\text {-total for } \\
\text { period }\end{array}$} \\
\hline & $\begin{array}{l}\text { Millions } \\
\text { of dollars }\end{array}$ & $\begin{array}{l}\text { Chapter as } \\
\% \text { of total } \\
\text { imports }\end{array}$ & $\begin{array}{l}1994 \\
\text { 2nd } \\
\text { half-yr. }\end{array}$ & 1995 & $\begin{array}{c}1996 \\
\text { Jan-Sep }\end{array}$ & $\begin{array}{l}\text { Reduc- } \\
\text { tions: }\end{array}$ & $\begin{array}{l}\text { Incr- } \\
\text { eases }\end{array}$ & Total & $\begin{array}{c}\text { Chap.f } \\
\text { total } \\
\text { changes }(\%)\end{array}$ & \\
\hline [1] & $116]$ & 2.36 & 10.00 & 10.38 & 10.50 & 0 & 10 & 10 & 0.06 & 48 \\
\hline 27 & 5541 & 11.24 & 6.94 & 9.95 & 8.34 & 110 & 34 & 144 & 0.87 & 93 \\
\hline 28 & 583 & 1.18 & 3.96 & 5.49 & 5.62 & 68 & 384 & 452 & 2.72 & 578 \\
\hline 29 & 2976 & 6.04 & 6.77 & 8.25 & 8.27 & 1524 & 1565 & 3089 & 18.60 & 2210 \\
\hline 39 & 1596 & 3.24 & 13.15 & 13.39 & 13.85 & 226 & 160 & 386 & 2.32 & 285 \\
\hline 48 & 919 & 1.86 & 9.50 & 12.02 & 12.71 & 38 & 286 & 324 & 1.95 & 220 \\
\hline 54 & 531 & 1.08 & 12.89 & 12.30 & 16.46 & 455 & 203 & 658 & 3.96 & 215 \\
\hline 55 & 286 & 0.58 & 15.31 & 14.52 & 17.81 & 247 & 78 & 325 & 1.96 & 142 \\
\hline 72 & 320 & 0.65 & 9.88 & 10.06 & 10.05 & 142 & 273 & 415 & 2.50 & 331 \\
\hline 73 & 377 & 0.76 & 12.41 & 14.86 & 14.97 & 91 & 196 & 287 & 1.73 & 282 \\
\hline 84 & 7990 & 16.20 & 19.31 & 17.98 & 16.95 & 2261 & 146 & 2407 & 14.49 & 1302 \\
\hline 85 & 5705 & 11.57 & 18.07 & 22.01 & 19.36 & 861 & 184 & 1045 & 6.29 & 645 \\
\hline 87 & 5560 & 11.28 & 22.46 & 34.72 & 37.65 & 369 & 259 & 628 & 3.78 & 220 \\
\hline $\begin{array}{c}90 \\
\text { Total rumber } \\
\text { of chopters }\end{array}$ & 1622 & 3.29 & 17.11 & 16.10 & 15.59 & 638 & 83 & 721 & 4.34 & 508 \\
\hline selected & 35167 & 73.70 & & & & 7030 & 3861 & $1089 !$ & 65.57 & 7256 \\
\hline Total NBM/SS & $493 \mathrm{H}$ & 100.00 & 12.07 & 13.07 & 13.10 & 10014 & 6599 & 16613 & 100,00 & $11 / 83$ \\
\hline
\end{tabular}

Source: Tabulation prepared by the authors on the basis of primary data.

${ }^{3}$ NBMUSS = Brazilian Nomenclature of Goods/Harmonized System.

FIGURE 5

Brazil: Simple average tariff rate, for totel Imports and for solected chapters (Per cent)

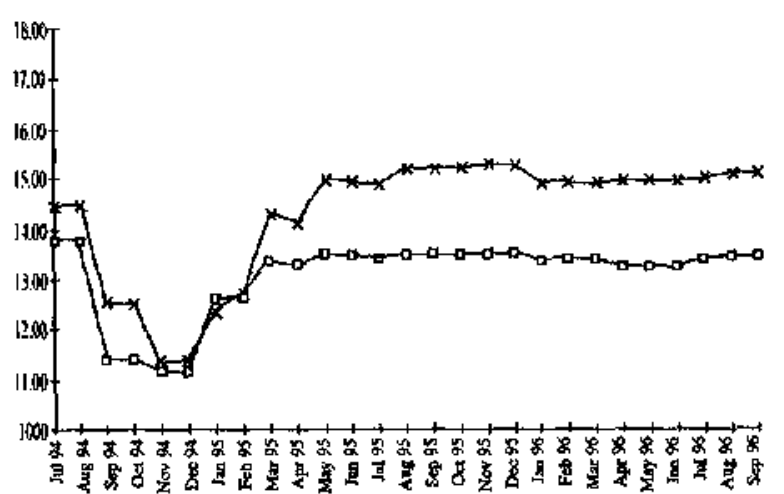

chanical equipment, electrical equipment and components, and the motor industry, where the tariff went down from $63.6 \%$ to $32.2 \%$ over the same period.
The sectoral data for the period from July 1994 w September 1996 also show that the "simple" rates displayed a varied trajectory." Thus, for example, in the case of mineral fuels, plastics and plastic products, paper and paperboard, inorganic chemical products, organic chemical products and motor vehicles, import duties reached their lowest level in the fourth quarter of 1994, while in the case of synthetic or artificial filaments and synthetic or artificial fibres they did so in the first quarter of 1995 . In the case of machinery and mechanical equipment, the "simple" rates display a systematic downward path.

What these different trajectories show is that -although the global indicators suggest that the first quarter of 1995 was the moment of greatest openness of the economy- the different forms of evolution of the sectoral rates also indicate that the policy of greater economic openness did not correspond to a generalized uniform movement, as may also be seen from the evolution of the standard deviations of the

\footnotetext{
11 Possible exceptions to this were the milling industry, cast iton, iron and steel products, and oplical instruments and equip ment, where the variations in the nominal rates were very small.
} 
TABLE 6

Brazll: Relation between value of imports and tarlf rate applled

\begin{tabular}{lccc}
\hline $\begin{array}{l}\text { Value of imports } \\
\text { per product } \\
\text { (millions of dollars) }\end{array}$ & Number of products & $\begin{array}{c}\text { Percentage share } \\
\text { in total value of } \\
\text { imports (1995) }\end{array}$ \\
\hline Over 20 & 369 & 56.97 & 14.93 \\
Over 50 & 132 & 42.62 & 27.88 \\
Over 100 & 52 & 31.06 & 36.43 \\
Over 150 & 34 & 26.88 & 50.01 \\
\hline
\end{tabular}

Source: Tabulation prepared by the authors on the basis of primary data

${ }^{a}$ Average rate between July 1994 and September 1996.

tariff rates already referred to. In other words, a period which is often associated in the minds of observers with trade openness actually covers a varied range of types of sectoral treatment.

A third aspect which emerges from analysis at the sectoral level is the behaviour of the "simple" and weighted rates. In some sectors, the weight of imports of products subject to higher rates than the sectoral average was enough to bring about a systematic rise in the weighted tariffs compared with the simple rates, as occurred in the case of mineral fuels, synthetic filaments (in 1994 and 1995) and automobiles and other land vehicles. On the other hand, in the case of inorganic chemical products, plastics and plastic products, paper and paperboard, electrical equipment and components, and optical instruments and equipment, the opposite took place because of the predominance in the imports of products subject to lower rates. ${ }^{12}$

Protection theory notes that in some situations the tariff level established may be excessive, giving rise to what is known as "tariff dilution" (a rate which exceeds the desirable level of protection). The same theory also notes that tariff levels may be so high as to make international trade inviable.

If the calculations show that some weighted tariffs are below the average for the sector, this may indicate that -taking account of the import structure and despite the generalized process of increased openness- in some industries there may have been some degree of excessive protection during, the period studied.

\section{III}

\section{Factors conditioning tariff policy}

The first aspect to be highlighted in the analysis of tariff policy in this period is the concern displayed, in the design of this policy, to stabilize the level of domestic prices in the broad sense. This concern is clearly reflected both in the preparation of the lists of

\footnotetext{
12 With regard to other sectors - such as milling industry produets, organic chemical products, cast iron, iron and steel products, and machinery and mechanical equipment- the degree of dispersion of the rales for the various products is only small, so that the structure of the weighted rates is similar to that of the "simpie" rates; in view of the relative homogeneity of the rates for the different products in these sectors, the estimation of the weighted rates does not suffer from the influence of the import value, which appears both in the numerator and the denominator of the formula used for calculation.
}

exceptions $^{13}$ and in the diagnosis underlying the whole process: it is based on the idea that access to products (especially inputs) at prices close to international levels helps to improve the efficiency of the entire production process, the competitiveness of domestic production, and the sustainability of the stabilization process itself.

Global data show a clear movement towards a generalized reduction in trade barriers, one of the most significant results of which has been an increase in the imported component of domestic supply:

\footnotetext{
1.9 It may be noted that these were prepared after the adoption of the Common Extemal Tariff.
} 
TABLB 7

Brazill: Some examples of products with five or more varlations in tarifi rales

\begin{tabular}{|c|c|c|c|}
\hline Chapter & Name & Number of products & Number of variations \\
\hline 15 & Oils and fats & 1 & 6 \\
\hline 29 & Organic chemical products & $\begin{array}{l}1 \\
6\end{array}$ & $\begin{array}{l}7 \\
5\end{array}$ \\
\hline 34 & Cleaning products & 12 & 6 \\
\hline 54 & Synthetic filaments & $\begin{array}{l}7 \\
5\end{array}$ & $\begin{array}{l}6 \\
7\end{array}$ \\
\hline 76 & Aluminium & 2 & 6 \\
\hline 83 & Base metal products & 1 & 6 \\
\hline 84 & Machinery and mechanical equipment & 1 & 6 \\
\hline & & 2 & 5 \\
\hline 85 & Blectrical machinery and equipment & 11 & 5 \\
\hline 87 & Motor vahicles & 61 & 5 \\
\hline
\end{tabular}

Source: Prepared by the authors on the basis of primary data.

according to estimates by Moreira and Correa (1996), the share of imports in the apparent consumption of manufacturing industry rose from $9.4 \%$ in 1993 to $15.5 \%$ in 1995 , especially imports of capital goods, whose share rose from $28 \%$ to $42 \%$ in the same period. ${ }^{14}$

Equally important was the decisive influence exerted on customs policy by the political decision to consolidate the process of formation of Mercosur. This factor -unprecedented in the country's economic policy -undoubtedly affected the results in late 1994 and early 1995.

Finally, this period is marked by a new approach, compared with Brazil's experience in recent decades, regarding the process of determining import duty rates. Traditionally, the tariffs for Brazil's imports were determined -since the 1957 Tariff Act- on the basis of negotiations between producers, marketers and the government authorities. This is a feature which has very few parallels in other countries; it might be maintained that this practice could have helped avoid the crises caused in other Latin American countries by the rate of trade reforms. At the same time, however, it must also be acknowledged that the influence of different interests could often have slowed down the desirable (or economically advisable) rate of changes in import duties.

\footnotetext{
14 As Moreira and Correa (1996) note, this occurred without any parallel increase in exports. For manufacturing as a whole, the export/output ratio remained almost constant: $14.5 \%$ in 1993 and $14.9 \%$ in 1995.
}

However its actions may be interpreted, the fact is that the existence of a customs policy committee made up of representatives of government and of the private sector (including representatives of agriculture, industry and trade) played an important part because it promoted transparency and joint definition of criteria for changes in the tariff structure. ${ }^{15}$

This mechanism disappeared in 1990 (its absence is therefore one of the special features of the period studied), and the definition of tariff rates became the responsibility of a sectoral ministry (the Ministry of Industry) and the Ministry of Finance.

It may be noted in this respect that the lack of such a policy-making instrument may involve costs. For example, if we analyse the rate of import duty on some specific products over a period of time we note that its evolution during the period in question does not display the stability recommended by protection theory as an important element for defining expectations and, ultimately, facilitating the action of the economic agents. Table 7 illustrates several such cases.

Protection theory suggests that the expectations of the economic agents -both producers and consumers- are influenced by their hope of deriving benefits from a given tariff structure. The more homogeneous that structure is, the fewer skews there will be in terms of added value, ${ }^{16}$ and hence the fewer distor-

\footnotetext{
15 For a description of the features, procedures and actions involved and some of the results obtained, see Baumtann and Morais (1988) and Baumann (1993).

${ }^{16}$ For an analysis of the levels of effective protection in recent times in Brazil, see Kume (1996).
} 
TABLE 8

Brazil: Examples of varlations in tarif rates for solectod products

\begin{tabular}{|c|c|c|c|c|c|c|c|c|}
\hline \multirow{2}{*}{$\frac{\text { Product }}{29.26 .90 .02 .00}$} & \multicolumn{8}{|c|}{ Evolution of import duty (percentage levels) } \\
\hline & $\begin{array}{c}\text { Adiponitrile } \\
7 / 1994 \\
15\end{array}$ & $\begin{array}{l}9 / 1994 \\
14\end{array}$ & $\begin{array}{l}12 / 1994 \\
2\end{array}$ & $\begin{array}{l}5 / 1995 \\
4\end{array}$ & $\begin{array}{l}11 / 1995 \\
8\end{array}$ & $\begin{array}{l}2 / 1996 \\
10\end{array}$ & $\begin{array}{l}4 / 1996 \\
2\end{array}$ & $\begin{array}{l}8 / 1996 \\
12\end{array}$ \\
\hline 34.01 .19 .03 .00 & $\begin{array}{c}\text { Industrial soap } \\
7 / 1994 \\
10\end{array}$ & $\begin{array}{l}1 / 1995 \\
11\end{array}$ & $\begin{array}{l}5 / 1995 \\
4\end{array}$ & ${ }_{6}^{11 / 1995}$ & $\begin{array}{l}2 / 1996 \\
8\end{array}$ & $\begin{array}{l}4 / 1996 \\
2\end{array}$ & $\begin{array}{l}8 / 1996 \\
18\end{array}$ & \\
\hline $54.02 .49 .02 .0 \mathrm{I}$ & $\begin{array}{c}\text { Acrylic dyes } \\
7 / 1994 \\
20\end{array}$ & $\begin{array}{l}9 / 1994 \\
16\end{array}$ & $\begin{array}{l}11 / 1994 \\
2\end{array}$ & $\begin{array}{l}4 / 1995 \\
0\end{array}$ & $\begin{array}{l}5 / 1995 \\
6\end{array}$ & $\begin{array}{l}2 / 1996 \\
10\end{array}$ & $\begin{array}{l}4 / 1996 \\
6\end{array}$ & $\begin{array}{l}8 / 1996 \\
16\end{array}$ \\
\hline 54.02 .49 .04 .01 & $\begin{array}{c}\text { Polypropylene } \\
7 / 1994 \\
20\end{array}$ & $\begin{array}{l}\text { es } \\
9 / 1994 \\
16\end{array}$ & $\begin{array}{l}11 / 1994 \\
2\end{array}$ & $\begin{array}{l}4 / 1995 \\
0\end{array}$ & $\begin{array}{l}5 / 1995 \\
6\end{array}$ & $\begin{array}{l}2 / 1996 \\
10\end{array}$ & $\begin{array}{l}4 / 1996 \\
6\end{array}$ & $\begin{array}{l}8 / 1996 \\
16\end{array}$ \\
\hline 84.22 .40 .99 .00 & Goods packagit & $\begin{array}{l}\text { machines } \\
7 / 1994 \\
20\end{array}$ & $\begin{array}{l}11 / 1994 \\
0\end{array}$ & $\begin{array}{l}1 / 1995 \\
19\end{array}$ & $\begin{array}{l}6 / 1995 \\
0\end{array}$ & $\begin{array}{l}7 / 1995 \\
19\end{array}$ & $\begin{array}{l}1 / 1996 \\
18\end{array}$ & \\
\hline 85.17 .10 .99 .00 & Telephone appa & $\begin{array}{l}\text { tus } \\
7 / 1994 \\
30\end{array}$ & $\begin{array}{l}1 / 1995 \\
19\end{array}$ & $\begin{array}{l}3 / 1995 \\
70\end{array}$ & $\begin{array}{l}5 / 1995 \\
63\end{array}$ & $\begin{array}{l}1 / 1996 \\
56\end{array}$ & $\begin{array}{l}4 / 1996 \\
30\end{array}$ & \\
\hline 87.03 & Passenger cars & $\begin{array}{l}7 / 1994 \\
\mathbf{3 5}\end{array}$ & $\begin{array}{l}9 / 1994 \\
20\end{array}$ & $\begin{array}{l}1 / 1995 \\
32\end{array}$ & $\begin{array}{l}2 / 1995 \\
70\end{array}$ & $\begin{array}{l}1 / 1996 \\
62\end{array}$ & $\begin{array}{l}4 / 1996 \\
70\end{array}$ & \\
\hline
\end{tabular}

Source: Prepared by the authors on the basis of primary data.

tions will be caused in resource allocation. Furthermore, the more stable this structure is over time, the longer will be the planning horizon of the agents and the greater the efficiency of resource allocation. Long-term projects need stable rules.

However, the data in table 7 show that for some products (in a ten-digit classification) the period between July 1994 and September 1996 was one of instability, with marked fluctuations in the rates of import duty. There is no set rule for knowing what the time interval between tariff changes should be, but it seems reasonable to assume that producers (and consumers) of a product which undergoes six or more changes in its rate of duty over a period of 27 months must have some difficulty in programming their activities with any degree of precision, especially when those variations are both upward and downward and are of considerable magnitude. Table 8 shows some examples of products where these fluctuations were quite marked and where the process of fixing import duties did not follow any clear line, whether in terms of establishing greater trade openness or creating a more autarkic system. Nor is there any clear sectoral rationale. Producers in such widely different sectors as the manufacture of cleaning products, machinery, yarns and automobiles all suffered marked variations without any apparent direction: fluctuations which amounted in some cases to as much as nineteen percentage points in one or the other direction within a period of six months.

The most likely explanation of this is that import policy pursued multiple objectives which were not always compatible with each other, such as giving broader access to imported goods and contributing to the price stabilization programme while -in some cases- reducing the costs of domestic producers of those goods. 


\section{IV}

\section{Summary and final remarks}

In this article we have sought to analyse the evolution of import tariffs in the first two years of application of the Plano Real (July 1994 to September 1996), by examining the whole structure of tariff rates. The period studied coincided with a marked intensification of the process of greater trade openness of the Brazilian economy, which began in 1988 and was stepped up as from 1990 with the definition of a downward movement of tariff rates.

In this period there was a process of trade liberalization -reflected in the average level of tariffs and the degree of dispersion of their structure- which reached its peak in the first quarter of 1995 . After that, there were various increases in tariff rates, differentiated by sectors, which led to greater dispersion of the tariff structure. At the same time, these events suggest that the average level of nominal import duties remained relatively constant since the second quarter of 1995, so that the behaviour of the total value of imports was determined by other elements.

This process affected practically $90 \%$ of the Brazilian import list and took place in stages which were associated with a process of openness in the broad sense, the partial advance application of the Mercosur Common Extemal Tariff structure, and the adoption of lists of exceptions.

Analysis of the process by sectors of production reveals (if we leave aside the particular cases of petroleum and automobiles, which received differential treatment and had significant weight in imports as a whole) that there was a direct relation between the nominal tariff rate and the value of imports for each product (which indicates a concern for specific sectors of production) and that there were marked variations during the period studied. Furthermore, the fact that in the case of some sectors the weighted rate (weighted by the value of imports) was below the simple average rate for a number of months indicates that there is room for reviewing the tariff levels in some cases.

These observations give grounds for some reflections on the design of import policy. In principle, this design should reflect a clear target function for the economic agents so that investment decisions may be based on the largest possible amount of information. This clarity stems not only from the identification of purposes but also from the manner of achieving the objectives. The Brazilian experience is unique and valuable in the sense that there was a collegiate body for this task. There are pros and cons with regard to this manner of operation, as a decision on goods manufactured by only a fow domestic producers may not be efficient if it is not based on ample information.

Moreover, protection should not be an aim in itself, nor should it be maintained without taking account of its alteration of the basic economic relations. In other words, there should be some degree of flexibility for making adjustunents, either by using a practice which is common in other countries (the application of non-tariff mechanisms) or by making corresponding changes in the exchange rate..$^{17}$ However, fluctuations in nominal tariff rates which exceed a certain level in a relatively short space of time are certainly not desirable, because tariffs represent only one of the price signals (along with the exchange rate and other factors) which are important for the agents concerned, and the direction of variation is not atways immediately identified. Theoretically, the ideal is indeed a single, uniform rate maintained in time, but this is not always feasible. One possibility that might be explored is the definition of possible margins of variation for given periods of time, as a way of reducing the excessive instability which marked the period studied.

(Original: Portuguese)

${ }^{17}$ This method was typical of Brazilian practice in the 1970 s and 1980 s, but its use should be viewed with caution in the light of the growing importance of external financial flows for the Brazilian economy and -in the period in question- the whole rationale of the stabilization process, which requires a relatively low and constant exchange rate. 
ANNEX 1

\section{Methodology used}

The aim of the study was to describe the policy followed in defining the rates of import duties in Brazil during the period from July 1994 to September 1996 and analyse the resulting structures. It was therefore necessary to work with the universe of products in the Brazilian Nomenclature of Goods, Harmonized System (13,428 products in the 10-digit classification) and examine all the documents published in the Official Gazette which involved changes in those rates.

The second step was to organize and hamonize the information on import duty rates according to the data of the Brazilian customs tariff (products classified at the 10-digit level under the Harmonized System) and the Common External Tariff (8-digit classification of the common Mercosur nomenclature). This process was carried out on the basis of the common root for each product (6-digit classification), using the compatibility scheme prepared for the Common External Tariff and published in customs reference works.

The third stage in the work was to determine the rates applicable to each product in July 1994 and then tabulate, for each succeding month, the changes made through resolutions or decrees. Of the 13,428 products, 11,183 underwent some type of change in the applicable rate and 939 underwent three or more changes in the period.

On the basis of this information, vectors of the rates applicable in each month to each product were then constructed.

In order to facilitate the analysis, the monthly data were grouped in quarters. The basic criterion used for this grouping was the assumption that the representative rate for each quarter was the rate which was in force for the longest period of time. On the basis of this assumption, we then calculated what we have called the "simple rate", which is actually the average of the rates applicable to each product, weighted by the period of applicability of the rates in each quarter.

This estimate enabled us to identify the sectors most strongly affected and the number of cases of increases or reductions in rates, and also to calculate the generic descriptive statistics: the mean, mode and standard deviation of the rates.

However, the evaluation of a tariff structure also requires that the estimated representative rate should reflect the relative importance of the various products in terms of their share of the total value of imports. A structure in which the tariffs are weighted by the value of imports of each product has more economic significance than a vector of simple nominal rates.

This raises the problen of defining an import structure which can be used as a reference for the weighting process. In the period studied a marked influence was exerted by the income-effects and price-effects deriving from the process of stabilization of dontestic prices, as well as the effect exerted on demand by the process of greater external trade openness. Consequently, the composition of Brazilian imports in 1994 and 1995 was very different from the structure in previous years.

In order to overcome this problem, we considered three alternative weighting structures:

i) as a structure "representative" of the period immediately before the adoption of the Plano Real we used the import structure observed in 1990-1993 (average import values for each product);

ii) as a reference value for testing substantive changes in import structure, we used the 1995 import structure;

iii) we assumed that a) changes in tariff rates have helped to change import values and also, because of the effect of this on certain products, that b) variations in the value imported affect decisions to change the levels of import duties. We also assumed (in a consciously arbitrary manner) that c) these effects took place with a lag of not more than one quarter. This gave rise to a third weighting criterion, in which the rates for a given quarter are weighted by the current value of imports in that quarter.

Special care was taken in the tabulation of the data for the fourth quarter of 1994, which is considered by various analysts to be the period of greatest intensification of the trade openness process. As we had a very detailed knowledge of the whole regulation process, it was possible to follow up closely, among other things, the effective relation between the Brazilian tariff structure and the Common External Tariff, leading us to make some reservations with regard to some conclusions frequently found in studies of this period.

The data on import duty rates were compiled from an analysis of the resolutions and decrees published in the Official Gazette of the Union during the period studied, as well as the foreign trade legislation published in customs reference works.

The data on the monthly value of imports of each product were obtained directly from the prinary processing carried out by the Ministry of Federal Revenues, which enabled us to calculate the weighted rates (weighted by value and by period of applicability) and to group the data by chapters (two digits of the Harmonized System) and by sub-periods. 
ANNEX 2

Brazil: Nominal percentage imporl duty rates for selected sectors, 1990-1996

\begin{tabular}{|c|c|c|c|c|c|c|c|c|c|c|c|c|c|c|}
\hline Period & Cha & Cha & Chap. 28 & Chap.29 & Chap.39 & Chap.48 & Chap. 54 & Chap.55 & Chap. 72 & Chap 73 & Chap.84 & Chap.85 & Chap 87 & Chap 90 \\
\hline 1990 & 28.75 & 5.00 & 13.55 & 24.21 & 32.26 & 26.31 & 25.53 & 30.00 & 21.99 & 26.95 & 36.56 & 38.89 & 63.57 & 29.97 \\
\hline 1991 & 21.15 & 1.49. & 7.70 & 17.12 & 25.91 & 15.09 & 24.37 & 30,00 & 16.43 & 22.73 & 28.90 & 31.79 & 48.72 & 25.63 \\
\hline 1992 & 12.08 & 0.53 & 7.07 & 15.69 & 21.86 & 12.04 & 21.17 & 25.00 & 13.98 & 18.78 & 24.72 & 26.84 & 40.63 & 21.24 \\
\hline 1993 & 9.90 & 0.57 & 5.10 & 13.03 & 16.28 & 10.49 & 21,21 & 24.26 & 11,09 & 17.29 & 20.29 & 22.11 & 32.18 & 19.34 \\
\hline 1994 & 9.48 & 0.41 & 4.52 & 12.30 & 14.74 & 10.49 & 18.06 & 19.07 & $10.2 \mathrm{t}$ & 13.35 & 19.37 & 19.01 & 27.39 & 17.77 \\
\hline 1995 & 10.40 & 9.95 & 5.49 & 8.25 & 13.39 & 12.02 & 12.30 & 14.52 & 10.06 & 14.86 & 17.98 & 22.01 & 34.72 & 16.10 \\
\hline 1996 & & & & & & & & & & & & & & \\
\hline (jan.sep.) & 10.50 & 8.34 & 5.62 & 8.27 & 13.85 & 1 & I & 1 & . & 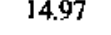 & 16.9 & .36 & .65 & 9 \\
\hline 1994 III & 10.00 & 7.24 & 4.25 & 9.41 & 14.03 & 9.50 & 16.37 & 18.06 & 10.22 & 12.78 & 19.37 & 18.34 & 24.99 & 17.45 \\
\hline 1994 IV & 10.00 & 6.65 & 3.66 & 4.13 & 12.28 & 9.50 & 9.40 & 12.55 & 9.54 & 12.04 & 19.24 & 17.80 & 19.93 & 16.77 \\
\hline 1995 I & 10.38 & 9.95 & 5.44 & 8.23 & 13.24 & 12.73 & 7.13 & 10,38 & 10.66 & 14.92 & 17.63 & 18.70 & 26.52 & 16.28 \\
\hline $1995 \mathrm{Il}$ & $10: 38$ & 9.95 & 5.46 & 8.26 & 13.35 & 12.02 & 10.76 & 13.55 & 9.95 & 14.80 & 18.34 & 23.52 & 37.49 & 16.28 \\
\hline $1995 \mathrm{JI}$ & 10.38 & 9.96 & 5.48 & 8.27 & 13.52 & 11.67 & 15.04 & 16.59 & 9.68 & 14.84 & 17.97 & 22.90 & 37.44 & 16.10 \\
\hline $1995 \mathrm{IV}$ & 10.38 & 9.96 & 5.57 & 8.26 & 13,46 & 11.67 & 16.26 & 17.57 & 9.95 & 14.87 & 17.97 & 22.90 & 37.44 & 15.74 \\
\hline 19961 & 10.50 & 8.32 & 5.60 & 8.27 & 13.85 & 12.46 & 16.42 & 17.81 & 10.04 & 1497 & 17.29 & 21.78 & 34.25 & 15.47 \\
\hline $1996 \mathrm{II}$ & 10.50 & 8.35 & 5.60 & 8.27 & 13.85 & 12.46 & 16.34 & 17.81 & 10.04 & 14,97 & 16.80 & 18.16 & 39.05 & 15.67 \\
\hline 1996111 & 10.50 & 8.35 & 5.65 & 8.27 & 13.85 & 13.21 & 16.62 & 17.81 & 10.05 & 14.97 & 16.78 & 18.13 & 39.64 & 15.64 \\
\hline
\end{tabular}

Source: Tabulation of primary data (see text).

Chap. 11 - Milling industry products; Chap. 27 - Mineral fuels and mineral oils; Chap. 28 - Inorganic chemical products; Chap. 29 - Organic chemical products; Chap. 39 -Plastics and products thereof; Chap. 48 - Paper and paperboard; Chap. 54 - Synthetic or artificial filaments; Chap. 55 - Synthetic oc artificial fibres; Chap. 72 - Cast iron, iron and steel; Chap. 73 - Cast iron, iron or steel, worked; Chap. 84 - Machinery and mechanical equipmest; Chep. 85 - Electrical equipment and components; Chap. 87 - Motor vehicles and other land transport equipment; Chap. 90 -Optical isstruments and equipment.

\section{Bibliography}

Baumann, R. (1993): A Political Economy Analysis of Import Tariff Policy in Brazil: 1980-1988, "Reformas - de política pública" series, No. 3, Santiago, Chile, Economic Commission for Latin Annerica and the Caribbean (ECLAC).

Baumant, R. and J.M. Morais (1988): A economia política da proteçäo no Brasil e a Rodada Uruguai, Texto para discussăo, No. 2, Rio de Janeiro, Institute of Applied Economic Research (IPEA), September.

Kume, H. (1996): A poltrica de importação no Plano Real e a estrutura de protefäo efetiva. Texto para discussăo, No. 423, Río de Janeiro, Institute of Applied Economic Research (IPEA), May.

Moreira, M. M. and P.G. Correa (1996): Abertura comercial e indústria: o que se pode esperar e o que se vem obtendo. Texto para discussão No. 49, Rio de
Janeiro, National Economic and Social Development Bank/Area de Planejamento (AP)/Central Bank of Brazil, Departamento Econômico (DEPEC):

Nonnenberg, M. (1996): Impacto dos financiamentos sobre a crescimento das importaföes brasileiras: 1992/95, Texto para discussão No. 432, Rio de Janeiro, Institute of Applied Economic Research (IPEA), August.

Pinheiro, A. C. and G. Bacha de Almeida (1995): Padróes setoriais da proteção na economia brasileira, in $\mathrm{E}$. Teixeira and D. Aguiar (eds.), Comércio internacional e comercializacáo agricola, Viçosa, Fund for the Financing of Studies and Projects/Fundação de Aroparo a Pesquisa do Estado de Minas Gerais (FAPEMIG). 